\title{
Peroxisomal L-Pipecolic Acid Oxidation Is Deficient in Liver from Zellweger Syndrome Patients
}

\author{
STEPHANIE J. MIHALIK, HUGO W. MOSER, PAUL A. WATKINS, DAVID M. DANKS,
} ALF POULOS, AND WILLIAM J. RHEAD

\author{
Department of Pediatrics [S.J.M., W.J.R.], University of Iowa, Iowa City, Iowa 52242, Kennedy Institute for \\ Handicapped Children [H.W.M., P.A.W.], Baltimore, Maryland, 21205, The Murdoch Institute [D.M.D.], Royal \\ Children's Hospital, Parkville, Victoria, Australia 3052, Department of Chemical Pathology [A.P.]. The Adelaide \\ Children's Hospital, North Adelaide, South Australia 5006
}

\begin{abstract}
L-Pipecolic acid, a cyclic imino acid produced during the degradation of lysine, accumulates in body fluids of infants with the generalized peroxisomal disorders, including Zellweger syndrome, neonatal adrenoleukodystrophy, and infantile Refsum disease. Peroxisome-enriched fractions from normal human liver oxidized $\mathrm{L}-\left[{ }^{3} \mathrm{H}\right]$ pipecolic acid to $\alpha-\left[{ }^{3} \mathrm{H}\right]$ aminoadipic acid (AAA). When human liver organelles were separated on a Percoll gradient, $L-\left[{ }^{3} \mathrm{H}\right]$ pipecolic acid oxidation activity (as measured by $\left[{ }^{3} \mathrm{H}\right] \mathrm{AAA}$ formation) most closely segregated with the peroxisomal marker, catalase, and was not associated with the mitochondria. L-Pipecolic acid oxidation was not inhibited by antimycin $A$ and rotenone and produced $\mathrm{H}_{2} \mathrm{O}_{2}$, consistent with its involving a peroxisomal oxidase.

We measured L-pipecolic acid oxidation in liver specimens from patients with peroxisomal disorders. While liver homogenates from adult $(n=5)$ and infant $(n=10)$ controls formed 47.1 \pm 6.6 and $48.3 \pm 10.0 \mathrm{pmol} \mathrm{AAA} /$ $\mathrm{mg}$ protein/h, respectively, Zellweger syndrome livers $(n$ $=8$ ) formed only $1.7 \pm 0.3 \mathrm{pmol} \mathrm{AAA} / \mathrm{mg}$ protein $/ \mathrm{h}$. Lpipecolic acid oxidation in normal infant livers was low at birth and increased with age, but Zellweger syndrome livers showed little activity at any age. Thus, the high circulating levels of L-pipecolic acid in Zellweger syndrome probably result from defective peroxisomal oxidation of $L$-pipecolic acid to AAA. (Pediatr Res 125: 548-552, 1989)
\end{abstract}

\section{Abbreviations}

AAA, $\alpha$-aminoadipic acid

FAD, flavin adenine dinucleotide

MOPS, 3- $N$-morpholinopropanesulfonic acid

L-Pipecolic acid accumulates in the body fluids of infants with generalized peroxisomal disorders including hyperpipecolic acidemia, Zellweger syndrome (cerebrohepatorenal syndrome), neonatal adrenoleukodystrophy, and infantile Refsum disease (1, $2)$. In these diseases, the peroxisomes are reduced in size and number $(2,3)$, and many enzymes normally localized in the

Received September 13, 1988; accepted December 30, 1988.

Correspondence Dr. William J. Rhead, Dept. of Pediatrics, University of Iowa Hospitals and Clinics, Iowa City, IA 52242.

Supported by USPHS Grants HD00380 (W.J.R.), DK33289 (W.J.R.), HD1098 (H.W.M.; P.A.W.), and HD07287 (S.J.M.); National Foundation March of Dimes Grants 5-297 and 1-876 (W.J.R.); a grant from the Muscular Dystrophy Association (W.J.R.); and the Brent W. Brees/Dows Metabolic Research Fund (W.J.R.). peroxisome have little activity (4-9). When patients with Zellweger syndrome and hyperpipecolic acidemia were given oral loading doses of pipecolic acid, their serum pipecolic acid levels were elevated for a prolonged period of time relative to controls (10-14). In earlier studies, we found that L-pipecolic acid is oxidized in the peroxisome in the cynomolgus monkey (15) and in the mitochondrion in the rabbit (16). If the peroxisome is also the site of L-pipecolic acid oxidation in humans, this activity may be lost in Zellweger syndrome and the other peroxisomal disorders. These present experiments with human liver demonstrate that 1 ) the $\mathrm{L}-\left[{ }^{3} \mathrm{H}\right]$ pipecolic acid oxidation assay previously developed for cynomolgus monkey tissues can be applied to postmortem human liver $(15,16) ; 2)$ L-pipecolic acid is oxidized to AAA in the peroxisome in humans, as in the monkey; and 3) the liver of infants with Zellweger syndrome oxidizes L-pipecolic acid abnormally.

\section{MATERIALS AND METHODS}

Materials. DL-[2,3,4,5,6- $\left.{ }^{3} \mathrm{H}\right]$ Pipecolic acid was custom synthesized by Amersham (Arlington Heights, IL). Ag $1 \times 8$ (100-200 mesh; $\left.\mathrm{CH}_{3} \mathrm{COO}^{-}\right)$and $\mathrm{Ag} 50 \times 8\left(200-400\right.$ mesh; $\left.\mathrm{H}^{+}\right)$resins were obtained from Bio-Rad (Richmond, CA). Pico IIB buffer was obtained from Pierce Chemical (Rockford, IL). Lithium citrate buffers and the AA-10 amino acid analyzer column were purchased from Beckman Instruments Inc. (Palo Alto, CA). All other enzymes, chemicals, and resins were obtained from Sigma Chemical Co. (St. Louis, MO).

Substrate preparation. DL-[2,3,4,5,6- $\left.{ }^{3} \mathrm{H}\right] \mathrm{Pipecolic}$ acid $(19 \mathrm{Ci} /$ $\mathrm{mmol}$ ) was adjusted to a sp act of $500 \mathrm{mCi} / \mathrm{mmol}$ with cold $\mathrm{L}$ pipecolic acid. To produce the L-enantiomer, the racemic compound was treated with D-amino acid oxidase and sodium borohydride as described by Chang et al. (method $\mathrm{Bb} ; 17$ ). This treatment quantitatively converts the D-enantiomer to the Lenantiomer by repeated oxidation of $\mathrm{D}$-pipecolic acid to $\Delta^{1}$ piperideine-2-carboxylic acid, which is then reduced by borohydride to DL-pipecolic acid (17). In each cycle of this reaction, the quantity of D-pipecolic acid is reduced by $50 \%$. The $L-[2,3,4,5,6-$ $\left.{ }^{3} \mathrm{H}\right]$ pipecolic acid was separated from reaction side products by elution from a $50 \times 0.9-\mathrm{cm} \mathrm{Ag} 50 \times 8\left(200-400\right.$ mesh; $\mathrm{Na}^{+}$ form) column with Pico IIB buffer at $52^{\circ} \mathrm{C}$; fractions $(1.0 \mathrm{~mL}$ ) were collected. The purified $\left[{ }^{3} \mathrm{H}\right]$ pipecolic acid fraction was desalted on a $35 \times 2.0-\mathrm{cm}$ Dowex $50 \times 8\left(100-200\right.$ mesh; $\mathrm{H}^{+}$ form) column using a $400 \mathrm{~mL}$ water wash, followed by elution of the $\mathrm{L}-\left[{ }^{3} \mathrm{H}\right]$ pipecolic acid with approximately $600 \mathrm{~mL}$ of $1-\mathrm{N}$ $\mathrm{NH}_{4} \mathrm{OH}$. The purified radioactive substrate was dried in a rotary evaporator and reconstituted in deionized water. 
Tissue preparations. All liver specimens were obtained at autopsy. Liver samples from infants and children with Zellweger syndrome and X-linked adrenoleukodystrophy were provided by Drs. H.W. Moser, D. M. Danks, and A. Poulos. C. Rebouche (University of Iowa, Iowa City, IA) supplied infant control liver specimens, and three of the adult control livers were supplied by Dr. T. Tephly (University of Iowa, Iowa City, IA). The remaining tissues were obtained from our laboratory. All postmortem liver specimens were obtained at necropsy and frozen at -70 to $-90^{\circ} \mathrm{C}$ until assay. The fresh liver sample used in the fractionation studies was obtained during organ harvest for transplantation. Organelles from this tissue were separated on Percoll gradients before freezing.

For postnuclear supernatants, 0.5 to $1.5 \mathrm{~g}$ of frozen liver was minced in about $3 \mathrm{vol}$ of buffer $(100-\mathrm{mM} \mathrm{KCl}, 50-\mathrm{mM}$ Tris, $\mathrm{pH}$ $8.33,1-\mathrm{mM}$ EGTA). To avoid activity losses from organelles broken by freezing, tissues were not rinsed with buffer, but were homogenized by four to five passes using a Potter-Elvehjem homogenizer with Teflon pestle and centrifuged for $30 \mathrm{~s}$ at 3900 $\times g$. The supernatant was used in L-pipecolic acid oxidation assays.

To prepare peroxisome-enriched fractions, a $10 \%$ (wt/vol) suspension of minced fresh human liver in $250-\mathrm{mM}$ sucrose, 5 mM HEPES, $\mathrm{pH} 7.5,1-\mathrm{mM}$ EGTA was disrupted with one to two passes of a Potter-Elvehjem homogenizer. Heavy (M, mitochondria-enriched) and light mitochondrial (L, peroxisome-enriched) fractions were made by a modification of the method of DeDuve (18), by sedimenting the heavy mitochondrial fraction at $3650 \times g$ for $10 \mathrm{~min}$. This empirical modification improved the separation of human peroxisomes from mitochondria. The heavy or light mitochondrial pellets were resuspended in gradient buffer (250-mM sucrose, 2-mM MOPS, pH 7.2, 1-mM EGTA (2); $420 \mu \mathrm{L} / \mathrm{g}$ wet tissue wt). For the gradient, $1 \mathrm{~mL}(20-30 \mathrm{mg}$ protein) of the light mitochondrial suspension was layered on 20 $\mathrm{mL}$ of a $36.5 \%$ Percoll solution $(7 \mathrm{~mL}$ isosmotic Percoll and 13 $\mathrm{mL}$ gradient buffer). The gradients self-formed in a $60 \mathrm{Ti}$ rotor during ultracentrifugation at $62000 \times g$ for $30 \mathrm{~min}$. Gradients were separated into $2 \mathrm{~mL}$ fractions by mechanically pumping from the bottom of the tube.

Assays. L-Pipecolic acid oxidation was assayed as in the cynomolgus monkey (15). The tissue preparation was combined with $60-\mu \mathrm{M} \mathrm{L}-\left[2,3,4,5,6-{ }^{3} \mathrm{H}\right]$ pipecolic acid $(500 \mathrm{mCi} / \mathrm{mmol})$, $100-\mu \mathrm{M}$ FAD, 1 -mM NAD ${ }^{+}, 5-\mathrm{mM} \mathrm{KCl}, 12-\mathrm{mM}$ Tris, $\mathrm{pH} 8.3$, and $0.1-\mathrm{mM}$ EGTA in a final vol of $60 \mu \mathrm{L}$ and incubated in a rotary shaking water bath at $37^{\circ} \mathrm{C}$ for $60 \mathrm{~min}$. Samples were then immediately applied to sequential anion exchange-cation exchange columns with $250 \mu \mathrm{L}$ of Ag $1 \times 8$ (100-200 mesh; acetate form) in the upper column and $250 \mu \mathrm{L}$ of Dowex $50 \times 8(100$ 200 mesh; $\mathrm{H}^{+}$form) in the lower column. Both columns were first eluted with $2.5 \mathrm{~mL}$ of water to recover the ${ }^{3} \mathrm{H}_{2} \mathrm{O}$ produced by the reaction. AAA was eluted quantitatively from the anion exchange column with $1.5 \mathrm{~mL}$ of $1-\mathrm{N}$ acetic acid. The $L-\left[{ }^{3} \mathrm{H}\right]$ pipecolic acid substrate bound exclusively to the cation exchange column and represented $>99 \%$ of the total radioactivity on this column. In all experiments, less than $0.5 \%$ of the substrate $\mathrm{L}_{-}{ }^{3} \mathrm{H}-$ pipecolic acid was converted to ${ }^{3} \mathrm{H}-\mathrm{AAA}$, and no other major radioactive products were detected (data available upon request). In addition, the peroxisome enriched light mitochondrial fraction from a fresh human liver sample was assayed using the method optimized for our rabbit mitochondrial studies (16); the pellet, suspended in 50-mM KCl, 25-mM HEPES, pH 7.5, 0.5-mM EGTA, 1.0-mM ATP, 2.5-mM $\mathrm{MgCl}_{2}$, and $10 \%$ (vol/vol) glycerol, was incubated with $60-\mu \mathrm{M} \mathrm{L}-\left[2,3,4,5,6-{ }^{3} \mathrm{H}\right]$ pipecolic acid $(500 \mathrm{mCi} / \mathrm{mmol}), 100-\mu \mathrm{M}$ FAD, and $1-\mathrm{mM}$ phenazine ethosulfate. The remaining incubation and separation conditions were identical to those in the standard assay described above. ${ }^{3} \mathrm{H}$-AAA formation was linear with respect to time and protein under standard assay conditions (data not shown). For postnuclear supernatants, the reported values are the mean of triplicate determinations; the other assays were performed in duplicate. Results are reported as pmol AAA formed/mg protein $/ \mathrm{h}$.
$\mathrm{H}_{2} \mathrm{O}_{2}$ formation was determined by a modification of the method of Duley and Holmes (19), which couples hydrogen peroxide production from oxidase reactions to the oxidation of $o$-dianisidine catalyzed by horseradish peroxidase. The reaction mixture contained, in $1-\mathrm{mL}$ vol, $320 \mu \mathrm{M}$ o-dianisidine $-2 \mathrm{HCl}$, 30 -mM Tris, pH 8.5, 80-mM KCl, 0.8-mM EGTA, postnuclear supernatants (1-1.5 mg protein), $10-\mathrm{mM} \mathrm{L}$-pipecolic acid, and $1.8 \mathrm{U}$ of horseradish peroxidase (Sigma Type VI). The L-pipecolic acid was omitted in blanks. The reaction was initiated by addition of L-pipecolic acid and was followed by monitoring the linear change in absorption at $460 \mathrm{~nm}\left(\epsilon_{460}=11.3 \times 10^{3} \mathrm{M}^{-1} \mathrm{~cm}^{-1}\right.$ for oxidized $o$-dianisidine) at $37^{\circ} \mathrm{C}$ from 30 to $60 \mathrm{~min}$. The reaction was linear with respect to added protein over this time interval. Omitting either L-pipecolic acid or peroxidase suppressed completely o-dianisidine oxidation.

Protein concentration was determined fluorometrically (20). Glutamate dehydrogenase, a mitochondrial matrix marker enzyme, was assayed by the method of Strecker (21); catalase, a peroxisomal marker enzyme, by the method of Aebi (22); and aryl esterase, a microsomal marker, by the method of Beaufay et al. (23). Student's $t$ test was the only statistical test used. All $p$ values are 1-tailed, and variation is expressed as SEM.

Amino acid analysis. A light mitochondrial fraction from fresh liver and a buffer blank were assayed for $\mathrm{L}-\left[{ }^{3} \mathrm{H}\right]$ pipecolic acid oxidation as described under "Assays." The anion exchange eluates were lyophilized, dissolved in Beckman Li-S sample buffer, and the sample injected onto a $0.24-\times 30-\mathrm{cm}$ Beckman AA-10 column in a Beckman $121 \mathrm{MB}$ Amino Acid Analyzer. Samples were analyzed on the Physiological Fluids Analysis, Single Column Lithium Program.

\section{RESULTS}

Characteristics of L-pipecolic acid oxidation in human liver. We performed amino acid analysis of the acidic products of $L_{-}$ pipecolic acid oxidation in a peroxisome-enriched human liver light mitochondrial fraction. A single peak coeluted with authentic $\alpha$-aminoadipic acid and contained $88 \%$ of the total radioactivity applied to the column; a buffer blank had no radioactivity under the AAA peak (data not shown). When a combined light and heavy mitochondrial fraction from human liver was fractionated on a Percoll gradient, L-pipecolic acid oxidation activity most closely paralleled that of catalase, a peroxisomal marker, and not those of either esterase, a microsomal marker, or glutamate dehydrogenase, a mitochondrial marker (Fig. 1). We recovered $50 \%$ of L-pipecolic acid oxidation activity from the gradient, comparable to that from monkey liver Percoll gradients (Mihalik SJ, Rhead WJ, unpublished observations). Recoveries of marker enzyme activities from the gradient ranged from 93 to $116 \%$.

To determine the assay suitable for human tissues, activity in a peroxisome-enriched human liver fraction was compared u ing two different assay systems, optimized for either rabbit nitochondrial or monkey peroxisomal L-pipecolic acid oxidation (15, 16). Sp act was 6-fold greater with the peroxisomal assay system than with the mitochondrial system $(675$ versus 117 pmol AAA/ $\mathrm{mg}$ protein/h). A mitochondria-enriched human liver fraction was assayed at both $\mathrm{pH} 7.5$ and 8.5 with and without added antimycin A $(100 \mu \mathrm{g} / \mathrm{mL})$ and rotenone $(25 \mu \mathrm{M})$. L-Pipecolic acid oxidation was not inhibited, also suggesting this activity is not mitochondrial (108\% of control; data not shown). In the peroxisome-enriched light mitochondrial fractions' $\mathrm{sp}$ act was 15 -fold greater than that in the postnuclear supernatant (44 $\mathrm{pmol} / \mathrm{mg}$ protein $/ \mathrm{h}$ ). Upon spectrophotometric assay with $o$ dianisidine as a chromophore and L-pipecolic acid as a substrate, human liver post nuclear supernatants formed $\mathrm{H}_{2} \mathrm{O}_{2}$ as a reaction product $(106 \pm 13 \mathrm{pmol} / \mathrm{mg}$ protein $/ \mathrm{min} ; \mathrm{n}=3)$, suggesting involvement of an oxidase. In the cynomolgus monkey, this membrane-associated activity is peroxisomal and has been extensively purified (Ref. 16; Mihalik S, Watkins P, Moser H, unpublished results). 

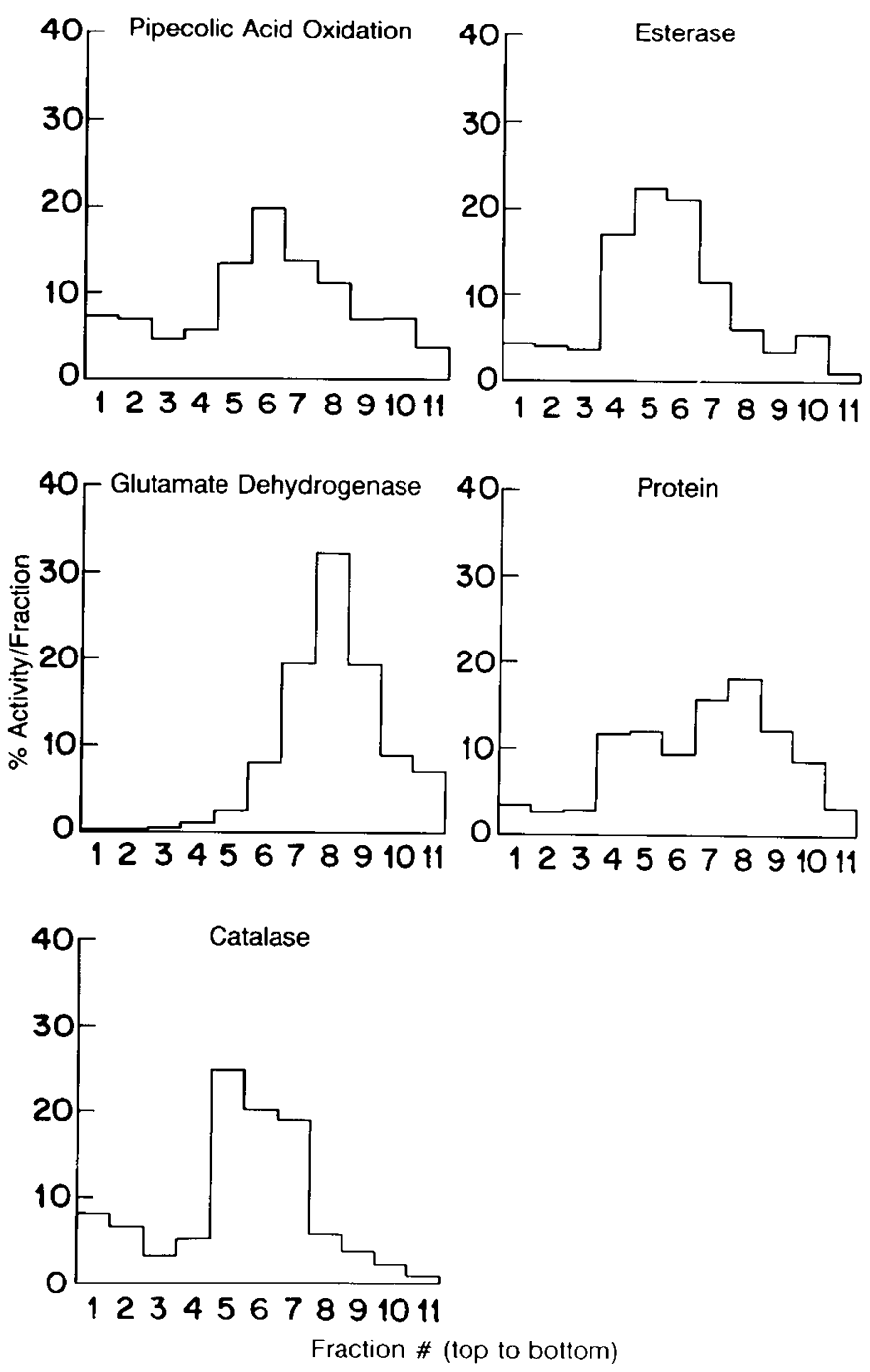

Fig. 1. Distribution of $\mathrm{L}_{-}\left[{ }^{3} \mathrm{H}\right]$ pipecolic acid oxidation activity in a human liver ML fraction separated on a Percoll gradient. A human liver combined heavy and light mitochondrial (ML) fraction was fractionated on a Percoll gradient as described in the text. Individual gradient fractions were assayed for L-Pipecolic acid oxidation activity in duplicate as described in the text. Individual fractions were also assayed for glutamate dehydrogenase, a mitochondrial marker, catalase, a peroxisomal marker, and aryl esterase, a microsomal marker.

L-Pipecolic acid degradation in liver from infants with Zellweger syndrome (Cerebrohepatorenal syndrome).

We assayed L-pipecolic acid oxidation in postnuclear supernatants from human postmortem livers (Table 1). Liver homogenates from infants with Zellweger syndrome had significantly less activity than did infant controls, adult controls, or children with X-linked adrenoleukodystrophy $(p<0.001)$. Mean activities for Zellweger syndrome infants were $3 \%$ of infant control values, $4 \%$ of adult control values, and $10 \%$ of X-linked adrenoleukodystrophy values. Catalase activity in Zellweger liver samples did not differ from that in any control group $(p>0.2)$.

Liver L-pipecolic acid oxidation activity from control and from Zellweger infants is plotted against age at death in Figure 2. Activity appears low for the first $2 \mathrm{wk}$ of life in normal individuals and then attains a level comparable to that of adults. Excluding the three neonates, infant controls had mean liver activities of $63 \pm 9.1 \mathrm{pmol} / \mathrm{mg}$ protein $/ \mathrm{h}(n=7)$. In contrast, the Zellweger infant livers always had activities less than $4 \mathrm{pmol} / \mathrm{mg}$ protein/ $\mathrm{h}$, and this activity did not increase with age. Only two liver specimens from X-linked adrenoleukodystrophy patients were available. These patients, who were intermediate in age (11 and
Table 1. L- ${ }^{3}$ HJpipecolic acid oxidation in liver from infants with Zellweger syndrome and from controls*

\begin{tabular}{ccc}
\hline & $\begin{array}{c}\mathrm{L}-\left[{ }^{3} \mathrm{H}\right] \text { pipecolic } \\
\text { acid oxidation } \\
\text { (pmol AAA } \\
\text { formed/mg } \\
\text { protein/h) }\end{array}$ & $\begin{array}{c}\text { Catalase } \\
(\mathrm{U} / \mathrm{mg} \\
\text { protein } / \mathrm{min})\end{array}$ \\
\hline Patient group & $47.1 \pm 6.6(5)$ & $185 \pm 42$ \\
\hline Adult controls & $48.3 \pm 10.0(10)$ & $115 \pm 18$ \\
Infant controls & $17.2 \pm 1.7(2)$ & $130 \pm 40$ \\
X-ALD pa- & & $157 \pm 19$ \\
tients $\dagger$ & $1.7 \pm 0.3(8)$ & 51 \\
ZS patients & $30.8(1)$ & \\
Hepatic disease &
\end{tabular}

* Postnuclear supernatants from frozen human liver samples were prepared and incubated with $60-\mu \mathrm{M} \mathrm{L}-\left[2,3,4,5,6-{ }^{3} \mathrm{H}\right]$ pipecolic acid $(500$ $\mathrm{mCi} / \mathrm{mmol}$ ), $100-\mu \mathrm{M}$ FAD, $1-\mathrm{mM} \mathrm{NAD}^{+}, 5-\mathrm{mM} \mathrm{KCl}, 12-\mathrm{mM}$ Tris, $\mathrm{pH}$ 8.3 , and $0.1-\mathrm{mM}$ EGTA in a rotary shaking water bath at $37^{\circ} \mathrm{C}$ for 60 min. Reaction products were separated as described in the text. Each value represents the mean of triplicate determinations with the SEM. The number of different liver specimens assayed is given in parentheses.

$\dagger \mathrm{X}$-ALD $=\mathrm{X}$-linked adrenoleukodystrophy.

$\ddagger Z \mathrm{ZS}=$ Zellweger syndrome. $p<0.001$ for ZS patients when compared to the first three groups.

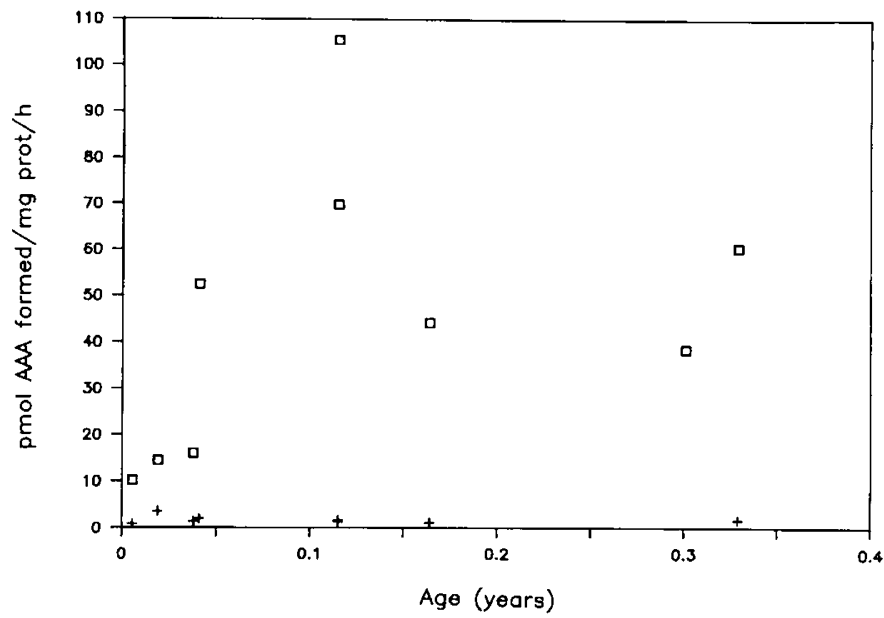

Fig. 2. Variation of L-pipecolic acid oxidation activity with age in liver from control infants and from infants with Zellweger syndrome. Postnuclear supernatants from frozen human liver samples were prepared and assayed as described in the text. $\square$, control; +, Zellweger syndrome.

13 y) between both control groups (infants older than 2 wk and adults), had less activity than either control group $(p<0.05)$. To determine if increased L-pipecolic acid oxidation in Zellweger syndrome resulted from liver damage, we assayed liver from one 9-mo-old infant with severe hepatic dysfunction of unknown etiology. Activity in this infant was $31 \mathrm{pmol} \mathrm{AAA} / \mathrm{mg}$ protein/ $\mathrm{h}, 8.5$-fold greater than the maximum in the Zellweger infants, and about half of that found in infants older than $2 \mathrm{wk}$.

\section{DISCUSSION}

In these studies, L-pipecolic acid oxidation has been assayed directly in human liver. As in the cynomolgus monkey $(15,16)$, the pathway for the conversion of L-pipecolic acid to AAA in humans appears located in the peroxisome. In livers from Zellweger infants, activity is reduced more than $95 \%$. Thus, defective peroxisomal L-pipecolic acid oxidation to AAA can explain the high circulating pipecolic acid levels in Zellweger syndrome patients.

In human liver fractionated on Percoll gradients, the distribution of L-pipecolic acid oxidation activity is most similar to that of catalase, although somewhat more diffuse (Fig. 1). Our 
separation of peroxisomes from microsomes was incomplete, as in some other studies using self-generating Percoll gradients (24, 25 ). We could not use other gradient media in these studies, such as Nycodenz and Metrizamide, because they inhibited L-pipecolic acid oxidation under all assay conditions (data not shown). The much greater activity found under assay conditions optimized for the peroxisomes, relative to those optimized for the mitochondria, also suggests that L-pipecolic acid oxidation is peroxisomal in humans. This activity is not affected by electron transport chain inhibitors and generates $\mathrm{H}_{2} \mathrm{O}_{2}$, also supporting a peroxisomal location.

We were concerned that both the delay until autopsy and subsequent lengthy freezing would degrade the L-pipecolic acid oxidation enzymes. However, a single Zellweger liver sample, removed in the first 2-3 min after death, did not differ in activity from all other Zellweger samples. Furthermore, the activity in fresh adult human liver was $44 \mathrm{pmol} \mathrm{AAA} / \mathrm{mg}$ protein $/ \mathrm{h}$, nearly identical to the mean of $47 \mathrm{pmol} A A A / m g$ protein $/ \mathrm{h}$ in frozen adult samples. Thus, the activity seems fairly stable after routine autopsy and freezing at $-70^{\circ} \mathrm{C}$. As only $50 \mu \mathrm{g}$ of liver is required for triplicate assays, we can presumably use liver samples obtained by needle biopsy to identify infants defective in L-pipecolic acid oxidation.

L-Pipecolic acid oxidation appeared lower in very young infants than in older infants and adults. This result was expected, as several studies (26-28) have reported pipecolic acid excretion in newborns. Hutzler and Dancis (27) found that plasma pipecolic acid levels were about $2.1 \mu \mathrm{M}$ after age 4 mo, whereas infants $1 \mathrm{wk}$ or less had levels averaging $12 \mu \mathrm{M}$. In contrast, serum pipecolic acid values ranges from 7 to $188 \mu \mathrm{M}$ in Zellweger syndrome patients aged 3 mo to 3 y (29).

Although Zellweger syndrome infants had L-pipecolic acid oxidation activities less than $5 \%$ of control, their liver catalase activity was similar to that in controls, as reported by others $(6$, $7,9,30)$. The enzyme(s) of L-pipecolic acid oxidation may have a fate similar to that of dihydroxyacetone phosphate acyltransferase $(2,31)$, another enzyme associated with the peroxisomal particulate subfraction, or of the peroxisomal $\beta$-oxidation enzymes (7-9), which are all deficient in Zellweger syndrome. Lazarow et al. (32) hypothesized that these multiple enzyme defects may result from the failure of a carrier which imports proteins into the peroxisomal matrix.

As the infant with hepatic disease had only mildly reduced Lpipecolic acid oxidation, the decreased activity in Zellweger syndrome probably does not result solely from hepatic dysfunction. Although Danks et al. (1) found that pipecolic acid was not excreted by infants with neonatal hepatitis, most hospitalized children with liver disease had plasma pipecolic acid levels in the high normal range, and two children with fatal hepatic disease had high plasma levels $(27,29)$. Thus, L-pipecolic acid oxidation activity may decrease in hepatic disease, but not to the degree observed in Zellweger syndrome. Decreased liver L-pipecolic acid oxidation in X-linked adrenoleukodystrophy was an unexpected finding. This disorder appears due to an isolated defect of peroxisomal very-long-chain fatty acid oxidation, and circulating levels of pipecolic acid are not elevated $(2,33)$. Liver specimens from more X-linked adrenoleukodystrophy patients are necessary before we can draw valid conclusions.

These studies confirm preliminary reports that Zellweger syndrome infants have defective L-pipecolic acid oxidation $(15,34)$. Moreover, we find that this activity is peroxisomal in man and yields both AAA and $\mathrm{H}_{2} \mathrm{O}_{2}$ as products. However, the origin of the deleterious effects, if any, of defective L-pipecolic acid oxidation are unclear. Newborn infants with Zellweger syndrome had plasma pipecolic acid levels similar to those in normal infants (35). As we can detect the enzyme defect in liver from young infants with Zellweger syndrome, the placenta or maternal circulation may regulate plasma L-pipecolic acid concentrations during the fetal period. In addition, hyperlysinemic patients with elevated pipecolic acid levels do not have neurologic dysfunction
(36). These findings suggest that elevated L-pipecolic acid levels per se are probably not toxic to the central nervous system. Identification of patients with isolated hyperpipecolic aciduria should help clarify the pathophysiologic consequences of elevated pipecolic acid levels.

Acknowledgments. The authors thank Dr. R. I. Kelley for his assistance and Drs. T. Tephly and C. Rebouche for donating control liver specimens.

\section{REFERENCES}

1. Danks DM, Tippett P, Adams C, Campbell P 1975 Cerebro-hepato-renal syndrome of Zellweger. J Pediatr 86:382-387

2. Schutgens RBH, Heymans HSA, Wanders RJA, van den Bosch H, Tager JM 1986 Peroxisomal disorders: A newly recognized group of genetic diseases. Eur J Pediatr 144:430-440

3. Goldfischer S, Moore CL, Johnson AB, Spiro AJ, Valsamis MP, Wisniewski HK, Ritch RH. Norton WT, Rapid I, Gartner LM 1973 Peroxisomal and mitochondrial defects in the cerebro-hepato-renal syndrome. Science 182:62-64

4. Datta NS, Wilson GN, and Hajra AK 1984 Deficiency of enzymes catalyzing the biosynthesis of glycerol-ether lipids in Zellweger syndrome. N Engl $J$ Med 311:1080-1083

5. Poulos A, Pollard AC, Mitchell JD, Wise D, Mortimer G 1984 Patterns of Refsum's disease. Phytanic acid oxidase deficiency. Arch Dis Child 59:222229

6. Wanders RJA, Kos M, Roest B, Meijer AJ, Schrakamp G, Heymans HSA, Tegelaars WHH, van den Bosch H, Schutgens RBH, Tager JM 1984 Activity of peroxisomal enzymes and intracellular distribution of catalase in Zellweger syndrome. Biochem Biophys Res Commun 123:1054-1061

7. Lazarow PB, Black V, Shio H, Fujiki Y, Hajra AK, Datta NS, Bangaru BS Dancis J 1985 Zellweger syndrome: biochemical and morphological studies in two patients treated with clofibrate. Pediatr Res 19:1356-1364

8. Schram AW, Strijland A, Hashimoto $T$, Wanders RJA, Schutgens RBH, van den Bosch H, Tager JM 1986 Biosynthesis and maturation of peroxisomal $\beta$-oxidation enzymes in relation to the Zellweger syndrome and infantile Refsum disease. Eur J Cell Biol 41 (suppl) 14:37(abstr)

9. Suzuki Y, Orii T, Mori M, Tatibana M, Hashimoto T 1986 Deficient activities and proteins of peroxisomal $\beta$-oxidation enzymes in infants with Zellweger syndrome. Clin Chim Acta 156:191-196

10. Gatfield PD, Taller E, Hinton GG, Wallace AC, Abdelnour GM, Haust MD 1968 Hyperpipecolatemia: a new metabolic disorder associated with neuropathy and hepatomegaly: a case study. Can Med Assoc J 99:1215-1233

11. Thomas GH, Haslam RHA, Batshaw ML, Capute AJ, Neidengard L, Ransom. JL 1975 Hyperpipecolic acidemia associated with hepatomegaly, mental retardation, optic nerve dysplasia and progressive neurological disease. Clin Genet 8:376-382

12. Trijbels JMF, Monnens LAH, Bakkeren JAJM, Van Raay-selten AHJ 1979 Biochemical studies in cerebro-hepato-renal syndrome of Zellweger: a disturbance in the metabolism of pipecolic acid. J Inherited Metab Dis 2:39-42

13. Burton BK, Reed SP, Remy WT 1981 Hyperpipecolic acidemia: clinical and biochemical observations in two male siblings. J Pediatr 99:729-734

14. Arneson DW, Tipton RE, Ward JC 1982 Hyperpipecolic acidemia. Arch Neurol 39:713-716

15. Mihalik SJ, Rhead WJ 1987 L-pipecolic acid is oxidized to $\alpha$-aminoadipic acid in the peroxisome of the human and monkey: subcellular localizatior: and initial characterization the pathway. Pediatr Res 21 (suppl): 292(abstr)

16. Mihalik SJ, Rhead WJ 1989 1,-Pipecolic acid oxidation in the rabbit and cynomolgus monkey: evidence for differing organellar locations and co uctor requirements in each species. J Biol Chem 264:2509-2517

17. Chang YF, Charles AK, Tilkin RB 1982 Assay of $\Delta^{1}$-piperideine-2-carboxylate and synthesis of $\mathrm{L}-\left[{ }^{14} \mathrm{C}\right]$ pipecolate from DL- $\left[{ }^{14} \mathrm{C}\right]$ pipecolate. Anal Biochem 125:376-385

18. DeDuve C 1971 Tissue fractionation past and present. J Cell Biol 50:20D-50D

19. Duley J, Holmes RS 1975 A spectrophotometric method for determining the activity of various rat tissue oxidases. Anal Biochem 69:164-169

20. Bohlen P, Stein S, Dairman W, Udenfriend S 1973 Fluorometric assay of proteins in the nanogram range. Arch Biochem Biophys 155:213-220

21. Strecker H 1955 L-Glutamate dehydrogenase from liver. In: Methods in Enzymology, vol 2. Academic Press, New York, pp 220-225

22. Aebi HE 1983 Catalase. In: Bergmeyer HU, Bergmeyer J, Grassl M (eds) Methods of Enzymatic Analysis, vol 3. Verlag Chemie, Weinheim, pp 273286

23. Beaufay H, Amar-Costesec A, Feytmans E, Thines-Sempoux D, Wibo M, Robbi M, Berthet J 1974 Analytical study of microsomes and isolated subcellular membranes from rat liver. J Cell Biol 61:188-200

24. Chu C, Schulz H 1985 3-Hydroxyacyl-CoA epimerase is a peroxisomal enzyme and therefore not involved in mitochondrial fatty acid oxidation. FEBS Lett 185:129-134

25. Mannaerts GP, Van Veldhoven P, Van Broekhoven A, Vandebroek G, Debeer LJ 1982 Evidence that peroxisomal acyl-CoA synthetase is located at the 
cytoplasmic side of the peroxisomal membrane. Biochem J 204:17-23

26. Woody NC, Pupene MB 1970 Excretion of pipecolic acid by infants and by patients with hyperlysinemia. Pediatr Res 4:89-95

27. Hutzler J, Dancis J 1983 The determination of pipecolic acid: method and results of a hospital survey. Clin Chim Acta 128:75-82

28. Govacrts L, Trijbels F, Monnens L, Van Raay-Selten A 1985 Pipecolic acid levels in serum and urine from neonates and normal infants: Comparison with values reported in Zellweger syndrome. J Inherited Metab Dis 8:87-91

29. Kelley RI, Moser HW 1984 Hyperpipecolicacidemia in neonatal adrenoleukodystrophy. Am J Med Genet 19:791-795

30. Santos MJ, Ojeda JM, Garrido J, Leighton F 1985 Peroxisomal organization in normal and cerebrohepatorenal (Zellweger) syndrome fibroblasts. Proc Natl Acad Sci USA 82:6556-6560

31. Zoeller RA, Raetz C 1986 Isolation of animal cell mutants deficient in plasmologen biosynthesis and peroxisome assembly. Proc Natl Acad Sci USA 83:5170-5174
32. Lazarow PB, Fujiki Y, Small G, Watkins P, Moser H 1986 Presence of the peroxisomal $22-\mathrm{kDa}$ integral membrane protein in the liver of a person lacking recognizable peroxisomes (Zellweger syndrome). Proc Natl Acad Sci USA 83:9193-9196

33. Singh I, Moser AE, Goldfischer S, Moser HW 1984 Adrenoleukodystrophy: Impaired oxidation of very long chain fatty acids in white blood cells, cultured skin fibroblasts, and amniocytes. Proc Natl Acad Sci USA 81:42034207

34. Wanders RJA, Romeyn GJ, van Roermund CWT, Schutgens RBH, Schutgens $\mathrm{H}$, van den Bosch $\mathrm{H}$, Tager JM 1988 Identification of L-pipecolic oxidase in human liver and its deficiency in the Zellweger syndrome. Biochem Biophys Res Commun 154:33-38

35. Dancis J, Hutzler J 1986 The significance of hyperpipecolatemia in Zellweger Syndrome. Am J Human Genet 38:707-711

36. Lam S, Hutzler J, Dancis J 1986 L-Pipecolaturia in Zellweger syndrome. Biochim Biophys Acta 882:254-257 